\title{
Effect of Integrated Nutrient Management on Growth and Yield attributes of Brinjal
}

\author{
Sukhlal waskel ${ }^{1}$, Sunil Kumar Jatav ${ }^{2 *}$ and S.S. Singh ${ }^{3}$ \\ ${ }^{1}$ Krishi Vigyan Kendra, Badgaon, Balaghat, India \\ ${ }^{2}$ Jawaharlal Nehru Krishi Vishwa Vidyalaya, Jabalpur, Madhya Pradesh, India \\ ${ }^{3}$ Mahatma Gandhi ChitrakootGramodayaVishwavidyalaya, Chitrakoot, \\ Madhya Pradesh, India \\ *Corresponding author
}

\section{A B S T R A C T}

\section{Keywords}

INM, FYM, Vegetable, Brinjal

Article Info

Accepted:

17 October 2019

Available Online:

10 November 2019
An experiment was conducted at the Rajola Farm of the Faculty of Agriculture Sciences, Mahatma Gandhi Chitrakoot Gramodaya Vishwavidyalaya, Chitrakoot, Madhya Pradesh, India during Kharif season 2014-2015. Twelve treatments of integrated nutrient management viz., (T0) control (no use of fertilizer), (T1) Farm Yard Manure (20 t/ha) + control, (T2) VC (10 t/ha) + control, (T3) control + Recommended Dose of Fertilizers (NPK), (T4) FYM (20 t/ha) + RDF (NPK), (T5) Vermi-compost (10 t/ha) + RDF (NPK), (T6) control + $75 \%$ RDF (NPK), (T7) FYM (20 t/ha) + 75\% RDF (NPK), (T8) VC (10 t/ha) + 75\% RDF (NPK), (T9) control + 50\% RDF (NPK), (T10) FYM (20 $\mathrm{t} / \mathrm{ha})+50 \% \mathrm{RDF}(\mathrm{NPK})$ and (T11) VC (10 t/ha) + 50\% RDF (NPK) were evaluated in Randomized Block Design (3 $X 4$ factorial) with three replications. Significantly higher values of yield attributes such as fruit yield per plot and fruit yield ton per ha were observed under VC @ $10 \mathrm{t} / \mathrm{ha}+75 \%$ RDF (NPK). However, significantly minimum values of yield attributes were observed under control FYM @ $20 \mathrm{t} / \mathrm{h}+75 \% \mathrm{RDF}$.

\section{Introduction}

Brinjal or eggplant (Solanum melongena L.) of the family Solanaceae is one of the important and popular vegetable crops grown in India and other parts of the world. Various sizes, shapes, colours and forms of cultivated as well as wild type of brinjal are found in India, white type brinjal fruits is said to be good for diabetic patients. Brinjal fruits have medicinal properties (Rajan and Markose, 2002). Some medicinal use of eggplant tissues and extract include treatment of diabetes, asthama, cholera, bronchitis and diarrhea, its fruit and 
leaves are reported to lower certain levels of blood cholesterol. The technique of organic farming is plays a role in cultivation of high value of vegetables crops. The productivity of brinjal can be increased by using several techniques viz., organic farming, integrated nutrient management and good hybrid seeds. Since the nutrient turnover in soil plant system is considerably high in intensive vegetable cultivation, neither the chemical fertilizer nor the organic manure alone can help achieve sustainable production (Khan et al., 2008). Moreover, the application of high input technologies such as chemical fertilizers, pesticides, herbicides improve the production but there is growing concern over the adverse effects of the use of chemicals on human health, soil productivity and environment quality.(Sharma et al., 2012). Bio fertilizers improve the quantitative and qualitative features of many plants (Yousefi et al., 2011). The integrated management of nutrient, in its proper perspective, may be adopted to support enhanced productivity and quality of vegetables (Kiran et al., 2010). Keeping in view the present investigation was carried out to study the effect of integrated nutrient management on the nutrient of brinjal.

\section{Materials and Methods}

The field experiment was conducted at the Rajola Farm of the Faculty of Agriculture Sciences, Mahatma Gandhi Chitrakoot Gramodaya Vishwavidyalaya, Chitrakoot, Madhya Pradesh, India during Kharif season (2014-2015). The field is situated at $24031^{\prime} \mathrm{N}$ latitude, $81015^{\prime} \mathrm{E}$ longitude, experiencing semi-arid and subtropical climate with mean annual precipitation of $100 \mathrm{~cm}$, minimum and maximum temperature of $2 \pm 1$ and $47 \pm 2^{\circ} \mathrm{C}$, respectively. The experiment was laid out in factorial randomized block design with each treatment being replicated three times and with Brinjal (cv Pusakranti) as the test crop. Each plot measured $2 \mathrm{~m} \times 3 \mathrm{~m}$ with distance between plant to plant and row to row was $60 \times 40 \mathrm{~cm}$. The nursery beds were $2 \mathrm{~m}$ wide, $2 \mathrm{~m}$ long and $15 \mathrm{~cm}$ high from the ground. Different combination of fertilizers, Farmyard manure and Vermicompost were applied with control. Nitrogen, phosphorus and potassium were applied, through urea, single super phosphate and murate of potash, respectively.

Twelve treatments of integrated nutrient management viz., (T0) control (no use of fertilizer), (T1) FYM (20 t/ha) + control, (T2) VC (10 t/ha) + control, (T3) control + RDF (NPK), (T4) FYM (20 t/ha) + RDF (NPK), (T5) VC (10 t/ha) + RDF (NPK), (T6) control + $75 \%$ RDF (NPK), (T7) FYM (20 t/ha) + 75\% RDF (NPK), (T8) VC (10 t/ha) + 75\% RDF (NPK), (T9) control + 50\% RDF (NPK), (T10) FYM (20 t/ha) + 50\% RDF (NPK) and (T11) VC (10 t/ha) + 50\% RDF (NPK)were evaluated in Randomized Block Design (3 X 4 factorial) with three replications. The observations were recorded viz., plant height $(\mathrm{cm})$, number of leaves per plant, leaf length $(\mathrm{cm})$, number of branches per plant, stem diameter $(\mathrm{cm})$ number of flower per plant, number of fruit per plant, fruit diameter $(\mathrm{cm})$, fruit length $(\mathrm{cm})$, fruit Weight $(\mathrm{g})$, fruit yield per plant $(\mathrm{Kg})$, fruit yield per plot $(\mathrm{Kg})$ and fruit yield per ha (q). The data were statistically analyzed according to the method suggested by Fisher (1950).

\section{Results and Discussion}

The maximum plant height was recorded at the time of maturity of plants under treatment T9 (VC @ 10 t/ha + 75\% RDF) has maximum plant height (95.78) compared to control. The maximum plant height of $93.83 \mathrm{~cm}$ recorded under treatment FYM@20 t/h + 75\% RDF (Table 1).

The numbers of leaves per plant were significantly by various treatments of organic manure and in combination with bio- 
fertilizers. The maximum number of leaves per plant (82.30) was recorded at VC @ 10 t/ha $+75 \%$ RDF significantly superior over all other treatment combinations. The better photosynthetic activity due to sufficient availability of NPK supplemented with FYM helped the plants to attain more vigor which in turn produced more number of leaves per plant as compared to NPK and FYM. The similar results were also reported earlier by Rao and Sankar (2001); Anburani and Manivannan (2002).

A maximum leaf length (24.53) and number of branches per plant (15.78) were recorded at VC@ 10 t/ha + 75\% RDF (NPK) which is consistent with the previous studies. The sufficient availability of (NPK) RDF with FYM might have helped the plants to attain more vigour through better photosynthetic activity, thereby producing longer leaves as compared to application of NPK as well as FYM alone. The similar results were also reported earlier by Mohd Rafi et al., (2002) and Naidu et al., (2002). The maximum numbers of flowers are observed per plant under FYM @20 t/h + 75\% RDF and combination VC@10 t/ha + 50\% RDF was significantly superior over all other treatment.

A maximum number of fruit per plant (17.44) were recorded at VC @ 10 t/ha+ $75 \%$ RDF (NPK) which is consistent with the previous studies. While minimum numbers of fruit are observed per plant $9.45 \mathrm{~cm}$ under Control+ RDF (NPK). The similar results were also reported earlier by Aminifard et al., (2010) and Biswas et al., (2015). The fruit length and fruit diameter $(\mathrm{cm})$ was significantly due to the VC @ 10 t/ha+ 50 \% RDF (NPK) treatment. However, the highest value is observed in the treatment 12.98 and 11.34. The find out that FYM @ $20 \mathrm{t} / \mathrm{h}+75 \%$ RDF
(NPK) at 223.22 recorded highest weight of fruit. It is clearly evident that the crop duration enhanced when the plants were treated with the FYM manure and recommended dose of fertilizers.

Statistical analysis proved that the maximum Fruit yield per plant was recorded in the case of treatment VC @ $10 \mathrm{t} / \mathrm{ha}+75 \% \mathrm{RDF}$ (NPK). Here VC @ 10 t/ha+ 75 \% RDF have yielded highest (4.25) followed by FYM @ 20 $\mathrm{t} / \mathrm{h}+75 \%$ RDF (NPK) (4.01).Several researchers also reported the similar results for fruit yield per plant under VC @ 10 t/ha+ 75 $\%$ RDF (NPK) Mishra et al., (2017) and; Patidar and Bajpai (2018).

Statistical analysis revealed that maximum fruit yield per plot and fruit yield ton per ha were significant under VC @ 10 t/ha+ $75 \%$ RDF (NPK). The noted data clearly indicate that the significantly in increased in the VC @ $10 \mathrm{t} / \mathrm{ha}+75 \%$ RDF (NPK) treated than the control. It is clearly noticed that the treatment vermicompost and recommended of fertilizers maximum fruit yield per plot of Brinjal over other treatments and minimum number of fruits were recorded in control conditions. Similar results were also reported by Mishra et al., (2017) and Kiran et al., (2010).

It is concluded that the treatment consisting of VC @ $10 \mathrm{t} / \mathrm{ha}+75 \% \mathrm{RDF}$ recorded that the highest brinjal yield per plant, fruit yield per plot, number of fruit plant and number of per plant. Integrated management of nutrients through appropriate level of fertilizer and vermicompost as superior over all other treatments combinations in relation to growth and yield for cultivation of brinjal to suit the environmental conditions of Chitrakoot region. 
Table.1 Effect of different treatment combinations of organic manures along with fertilizers on growth, yield attributes traits of Brinjal

\begin{tabular}{|c|c|c|c|c|c|c|c|c|c|c|c|c|c|c|c|c|}
\hline \multirow[t]{2}{*}{ Treatments } & \multicolumn{3}{|c|}{ Plant Height (cm) } & \multicolumn{3}{|c|}{ No. of leaves per plant } & \multirow{2}{*}{$\begin{array}{l}\text { Leaf } \\
\text { Length } \\
(\mathrm{cm})\end{array}$} & \multirow{2}{*}{$\begin{array}{c}\text { No. of } \\
\text { Branches } \\
\text { per plant }\end{array}$} & \multirow{2}{*}{$\begin{array}{c}\text { Flower } \\
\text { per } \\
\text { plant }\end{array}$} & \multirow{2}{*}{$\begin{array}{l}\text { No. } \\
\text { Fruit } \\
\text { per } \\
\text { plant }\end{array}$} & \multirow{2}{*}{$\begin{array}{l}\text { Length } \\
\text { fruit } \\
\text { (cm) }\end{array}$} & \multirow{2}{*}{$\begin{array}{c}\text { Fruit } \\
\text { Diameter } \\
(\mathbf{c m})\end{array}$} & \multirow{2}{*}{$\begin{array}{l}\text { Weight } \\
\text { of fruit }\end{array}$} & \multirow{2}{*}{$\begin{array}{l}\text { Fruit } \\
\text { yield } \\
\text { per } \\
\text { plant }\end{array}$} & \multirow{2}{*}{$\begin{array}{l}\text { Fruit } \\
\text { yield } \\
\text { per } \\
\text { plot }\end{array}$} & \multirow{2}{*}{$\begin{array}{c}\text { Fruit } \\
\text { yield ton } \\
\text { per ha. }\end{array}$} \\
\hline & $\begin{array}{c}30 \\
\text { DAT }\end{array}$ & $\begin{array}{c}60 \\
\text { DAT }\end{array}$ & $\begin{array}{c}90 \\
\text { DAT }\end{array}$ & $\begin{array}{c}30 \\
\text { DAT }\end{array}$ & $\begin{array}{c}60 \\
\text { DAT }\end{array}$ & $\begin{array}{c}90 \\
\text { DAT }\end{array}$ & & & & & & & & & & \\
\hline Control & 21.77 & 65.20 & 84.20 & 22.50 & 51.58 & 65.83 & 16.50 & 10.25 & 15.28 & 10.28 & 6.98 & 5.45 & 199.20 & 1.83 & 52.72 & 21.96 \\
\hline $\begin{array}{c}\text { FYM @ 20 } \\
\text { t/ha+ control }\end{array}$ & 23.17 & 77.08 & 91.66 & 23.20 & 59.55 & 76.55 & 20.55 & 11.88 & 14.41 & 14.41 & 9.86 & 8.36 & 218.08 & 2.88 & 79.30 & 33.03 \\
\hline $\begin{array}{l}\text { VC @ } 10 \text { t/ha+ } \\
\text { control }\end{array}$ & 23.41 & 78.17 & 93.10 & 24.47 & 61.54 & 77.57 & 18.57 & 12.54 & 17.17 & 15.17 & 7.62 & 6.12 & 219.17 & 3.05 & 88.18 & 36.73 \\
\hline $\begin{array}{c}\text { Control+ } \\
\text { RDF(NPK) }\end{array}$ & 22.20 & 65.83 & 82.58 & 23.73 & 57.55 & 74.02 & 20.60 & 11.55 & 13.45 & 9.45 & 6.95 & 5.45 & 193.83 & 3.40 & 46.14 & 19.21 \\
\hline $\begin{array}{c}\text { FYM @ } 20 \mathrm{t} / \mathrm{h}+ \\
\text { RDF }\end{array}$ & 21.65 & 74.55 & 90.55 & 24.47 & 64.83 & 81.22 & 19.56 & 1383 & 16.55 & 13.55 & 9.00 & 7.50 & 216.55 & 3.56 & 72.50 & 30.19 \\
\hline $\begin{array}{l}\text { VC @ } 10 \text { t/ha+ } \\
\text { RDF(NPK) }\end{array}$ & 22.63 & 76.57 & 91.54 & 23.90 & 65.78 & 82.30 & 24.53 & 15.78 & 15.57 & 14.57 & 7.35 & 5.85 & 217.57 & 3.84 & 76.79 & 31.98 \\
\hline $\begin{array}{c}\text { Control+ 75\% } \\
\text { RDF(NPK) }\end{array}$ & 21.20 & 72.02 & 86.55 & 23.40 & 56.45 & 73.60 & 20.35 & 11.87 & 13.45 & 12.45 & 8.80 & 7.30 & 214.02 & 2.57 & 64.67 & 26.93 \\
\hline $\begin{array}{c}\text { FYM @ } 20 \text { t/h + } \\
75 \% \text { RDF } \\
\text { (NPK) }\end{array}$ & 25.24 & 81.22 & 93.83 & 23.77 & 63.55 & 79.56 & 21.22 & 13.66 & 19.22 & 16.22 & 9.67 & 8.09 & 223.22 & 4.01 & 100.84 & 42.01 \\
\hline $\begin{array}{c}\text { VC@ } 10 \text { t/ha+ } \\
75 \% \\
\text { RDF(NPK) }\end{array}$ & 25.75 & 81.30 & 95.78 & 24.60 & 63.92 & 81.19 & 22.30 & 13.10 & 19.44 & 16.44 & 10.75 & 9.22 & 231.30 & 4.25 & 106.67 & 44.44 \\
\hline $\begin{array}{c}\text { Control+ 50\% } \\
\text { RDF(NPK) }\end{array}$ & 21.87 & 72.60 & 86.45 & 23.47 & 54.20 & 66.20 & 17.20 & 10.45 & 13.18 & 12.18 & 7.57 & 6.03 & 213.60 & 2.09 & 61.28 & 25.52 \\
\hline $\begin{array}{c}\text { FYM @ } 20 \mathrm{t} / \mathrm{h}+ \\
50 \% \text { RDF } \\
\text { (NPK) }\end{array}$ & 20.86 & 78.56 & 93.55 & 22.27 & 61.60 & 78.08 & 21.41 & 13.55 & 18.49 & 15.49 & 8.01 & 6.51 & 219.56 & 3.15 & 89.55 & 37.30 \\
\hline $\begin{array}{c}\text { VC@ } 10 \text { t/ha+ } \\
50 \% \\
\text { RDF(NPK) }\end{array}$ & 23.80 & 80.19 & 93.92 & 24.57 & 63.10 & 79.17 & 19.17 & 13.92 & 20.39 & 15.39 & 12.98 & 11.34 & 221.19 & 3.51 & 96.58 & 40.23 \\
\hline $\mathrm{SE} \pm$ & 0 & 1.037 & 0.782 & - & 0.782 & 1.037 & 0.689 & 0.508 & 0.614 & 0.614 & 0.505 & 0.496 & 1.037 & 0.022 & 2.430 & 0.845 \\
\hline CD at $5 \%$ & & 3.043 & 2.294 & - & 2.294 & 3.043 & 2.022 & 1.490 & 1.800 & 1.800 & 1.482 & 1.454 & 3.043 & 0.064 & 7.128 & 2.480 \\
\hline
\end{tabular}




\section{References}

Aminifard, M. H., Aroiee, H., Fatemi, H., Ameri, A., Karimpour, S. 2010. Response of eggplant (Solanum melongena L.) to different rates of nitrogen under field conditions. Journal Cent. Euro. Agric. 11(4): 453458.

Anburani, A. and Manivannan, K. 2002. Effect of integrated nutrient management on growth in brinjal (Solanum melongena L.) cv. Annamalai. South Indian Horticulture, 50(4/6): 377-386.

Biswas, M., Sarkar, DR., Asif, MI., Sikder, RK., Mehraj, H., Jamal Uddin, AFM. 2015. Nitrogen Levels on Morphological and Yield Response of BARI Tomato-9. J Sci. Tech. Environ. Inform. 1(2): 68-74.

Fisher, RA. 1950. Handbook of Agriculture statistics. Achal Prakashan Mandir, pp. 332-334.

Khan, M.S., Shil, N.C., and Noor, S. 2008. Integrated Nutrient Management for Sustainable Yield of Major Vegetable Crops in Bangladesh. Bangladesh Journal of Agriculture and Environment. 4: 81-94.

Kiran, J., Vyakarana, B.S., Raikar, S.D., Ravikumar, G.H. and Deshpande, V.K. 2010. Seed yield and quality of brinjal as influenced by crop nutrition. Indian Journal of Agricultural Research, 44(1): 1-7.

Mishra,VK., Kumar, S. and Pandey, VK. 2017. Effect of Organic Manure and
Bio-Fertilizers on Growth, Yield and Quality of Brinjal (Solanum melongena L.). Int. J. Pure App. Biosci. 6(1): 704-707.

Patidar, P and Bajpai, R. 2018. Effect of integrated nutrient management (INM) on yield parameters of Brinjal. International Journal of Chemical Studies 6(3): 1158-1160.

Rao, T.S.S. and Sankar, C.R. 2001. Effect of organic manure on growth and yield of brinjal. South Indian Horticulture, 49(Special): 288-291.

Rajan, S. and Markose, B.L. 2002. Propagation of Horticultural Crops. Horticultural Science Series, 6: 94.

Sharma, J.P., Rattan, P. and Kumar, S. 2012. Response of vegetable crops to use of integrated nutrient management practices. SABB Journal of Food and Agriculture Science, 2(1): 15-19.

Thingujam U, Pati1 S, Khanam R, Pari1 A., Ray K., Phonglosa A and Kallol Bhattacharyya 2016. Effect of integrated nutrient management on the nutrient accumulation and status of post-harvest soil of brinjal (Solanum melongena L.) under Nadia conditions (West Bengal), India. Journal of Applied and Natural Science 8 (1): 321 $-328$.

Yousefi, A.A., Khavazi, K., Moezi, A.A., Rejali, F. and Nadian, H.A. 2011. Phosphate solubilizing bacteria and Arbuscular mycorrhizal fungi impacts on inorganic phosphorus fractions and wheat growth. World Applied Sciences Journal, 15(9): 1310-1318.

\section{How to cite this article:}

Sukhlal Waskel, Sunil kumar Jatav and Singh, S.S. 2019. Effect of Integrated Nutrient Management on Growth and Yield attributes of Brinjal. Int.J.Curr.Microbiol.App.Sci. 8(11): 1849-1853. doi: https://doi.org/10.20546/ijcmas.2019.811.217 